\title{
Distribution patterns of Procamallanus (Spirocamallanus) inopinatus (Nematoda: Camallanidae) and its interactions with freshwater fish in Brazil
}

\author{
Padrões de distribuição de Procamallanus (Spirocamallanus) inopinatus \\ (Nematoda: Camallanidae) e suas interações com peixes de água doce do Brasil \\ Lígia Rigôr Neves ${ }^{1}$ (D); Luís Mauricio Abdon Silva² (1); Alexandro Cezar Florentino ${ }^{1}$ (1); Marcos Tavares-Dias ${ }^{1,3 *}$ (1) \\ 'Programa de Pós-graduação em Biodiversidade e Biotecnologia - Rede Bionorte, Universidade Federal do Amapá - UNIFAP, Macapá, AP, Brasil \\ ${ }^{2}$ Grupo de Pesquisa Aquática - NUPAq, Instituto de Pesquisas Cientificas e Tecnológicas do estado do Amapá - IEPA, Macapá, AP, Brasil \\ ${ }^{3}$ Empresa Brasileira de Pesquisa Agropecuária - Embrapa Amapá, Macapá, AP, Brasil
}

\begin{abstract}
How to cite: Neves LR, Silva LMA, Florentino AC, Tavares-Dias, M. Distribution patterns of Procamallanus (Spirocamallanus) inopinatus (Nematoda: Camallanidae) and its interactions with freshwater fish in Brazil. Braz J Vet Parasitol 2020; 29 (4): e012820. https://doi.org/10.1590/S1984-29612020092
\end{abstract}

\begin{abstract}
This study used information about Procamallanus (Spirocamallanus) inopinatus Travassos, Artigas \& Pereira, 1928 that had been published over a period of more than 90 years to investigate the infection and distribution patterns of this nematode in teleost freshwater fish in Brazil. This study was carried out using 181 samples from 82 fish species in 19 families within the five orders, with predominance of Characiformes species (71.6\%). We organized a matrix-based parasite-host system in which the fish species were classified in different trophic levels and parasitic infection parameters according data available on host fish species with different life histories and geographic distributions across Brazilian hydrographic basins. Procamallanus (S.) inopinatus showed prevalence ranging from low to moderate, low abundance, low intensity, typically aggregated dispersion, and preferential infection of the hosts' gastrointestinal tract. There was difference in prevalence between detritivorous, omnivorous, carnivorous and piscivorous hosts, but no difference in intensity and abundance was found due to similarity in the communities of this endoparasite among the host fish species. The geographic distribution of this parasite encompasses the river of the Amazon, Paraná, São Francisco, North Atlantic, South Atlantic and Eastern basins. Lastly, suggestions regarding the life cycle of $P$. (S.) inopinatus, with its potential intermediate hosts, were discussed.
\end{abstract}

Keywords: Endoparasite, freshwater fish, infection, nematode.

\begin{abstract}
Resumo
O objetivo deste estudo foi utilizar as informações sobre a Procamallanus (Spirocamallanus) inopinatus Travassos, Artigas \& Pereira, 1928, publicadas ao longo de mais de 90 anos (1928 e 2019), para a busca de padrões de infecção e distribuição desse nematoide em peixes de teleósteos de água doce, no Brasil. Este estudo foi realizado usandose 181 amostras de 82 espécies de peixes de 19 famílias, distribuídas em cinco ordens, com predominância de espécies de Characiformes (71.6\%). Foi organizado um sistema parasito-hospedeiro em matrizes com espécies de peixes de acordo com cinco níveis tróficos. Foram usados parâmetros de infecção parasitária (prevalência, intensidade e abundância), conforme os dados disponíveis para peixes hospedeiros com diferentes histórias de vida e distribuição geográfica em diferentes bacias do Brasil. Procamallanus (S.) inopinatus mostrou prevalência variando de baixa a moderada, baixa abundância, baixa intensidade, dispersão tipicamente agregada e infecção preferencial pelo trato gastrointestinal dos hospedeiros. Houve diferença na prevalência entre hospedeiros detritívoro, onívoro, carnívoro e piscívoro, mas não foram encontradas diferenças na intensidade e abundância de $P$. (S.) inopinatus, devido a uma similaridade na comunidade desse endoparasito entre os hospedeiros. Esse parasito tem distribuição geográfica nos sistemas das bacias do Rio Amazonas, Rio Paraná, Rio São Francisco, Atlântico Norte, Atlântico Sul e Leste, e esses achados foram discutidos. Por fim, o ciclo de vida de $P$. (S.) inopinatus, com potenciais hospedeiros intermediários, foi finalmente sugerido e discutido.
\end{abstract}

Palavras-chave: Endoparasito, peixes de água doce, infecção, nematoide. 


\section{Introduction}

Over recent years, parasites have been recognized as important components of global biodiversity (Luque \& Poulin, 2007; Luque et al., 2017). There is now a consensus that parasites play a key role in ecosystems (Azevedo et al., 2010; Gonçalves et al., 2016; Hoshino et al., 2016), since they can control the density of host fish communities and keep the food web stable. Among these parasite groups is the phylum Nematoda Rudolphi, 1808, which consists of numerous species distributed across the various zoogeographic regions of the world.

Nematoda is a taxon of endoparasites that has high diversity in South American fish, with a total of 303 known species, of which 143 species are known to infect Brazilian hosts (Luque et al., 2017). In Brazil, although the freshwater fish nematode fauna has been studied since the beginning of the $20^{\text {th }}$ century (Luque et al., 2017), inventories that also include the diversity of this helminth taxon have only recently been published. Such studies were carried out on different species of fish in certain locations in the country: for example, the region of the middle and upper Paraná River, in the state of Paraná (Takemoto et al., 2009; Kohn et al., 2011), and Guandu River, in the state of Rio de Janeiro (Azevedo et al., 2010). This information is useful in aiding understanding of the biodiversity and geographic distribution of parasite species and the interactions of the host-parasite system. However, there are still several unresolved questions about the distribution patterns of the most abundant taxa of nematodes in freshwater fish throughout their geographic distribution in Brazil.

Nematodes are important endoparasites that infect freshwater, brackish and marine fish. They constitute a significant part of the parasite fauna in different ecosystems around the world. Associations of these parasites with their host fish usually include larval or adult stages, as components of their parasitic communities (Travassos et al., 1928; Moravec, 1998; Takemoto et al., 2009; Kohn et al., 2011; Gonçalves et al., 2016; Almeida-Berto et al., 2018). These endoparasites are equipped with an alimentary canal and, therefore, they are free to circulate through the intestine of the host fish. In general, they can inhabit particularly the digestive tract beside other viscera of the hosts, but some species seem to have a preference for certain infection sites in their hosts and show pathogenicity depending on the levels of parasitism. High levels of infection can affect the growth of host fish and cause mortality (Geets \& Ollevier, 1996; Moravec, 1998; Gaines et al., 2012; Fujimoto et al., 2018).

Camallanidae Railliet \& Henry, 1915, is a monophyletic family of Nematoda with three known genera, including Procamallanus Baylis, 1923, which infects marine and freshwater fish and has worldwide distribution. Procamallanus (Spirocamallanus) inopinatus Travassos, Artigas \& Pereira, 1928, is a camallanid that was initially described as Leporinus spp., in the Mogi-Guaçu River, in the state of São Paulo, Brazil (Travassos et al., 1928). This nematode species of freshwater fish has distribution in South American countries such as Brazil, Argentina, Peru, Paraguay and Venezuela (Moravec et al., 1997; Moravec, 1998; Hamann, 1999; Takemoto et al., 2009; Chemes \& Takemoto, 2011; Kohn et al., 2011; Gonçalves et al., 2016; Almeida-Berto et al., 2018; Rivadeneyra et al., 2020). Despite this wide biogeographic distribution, the life cycle of $P$. (S.) inopinatus remains unknown, since no detailed studies on the association between this nematode and its host fish have yet been carried out.

In fish in the Amazon River basin system, infection by $P$. (S.) inopinatus has been found to be higher during the rainy season (Gonçalves et al., 2016; Fujimoto et al., 2018), because during this season the hosts have highest access to food containing infective stages of this nematode species. In the Paraná River system, $P$. (S.) inopinatus was found infecting Astyanax paranae Eigenmann, 1914 only in highly polluted areas, thus indicating that this nematode can be used as a bioindicator (Ribeiro et al., 2013). This nematode feeds on nutrients that have been processed by the host fish and it can cause intestinal damage due to inflammation, desquamation, hypertrophy, formation of fibrous capsules, loss of villi and necrosis in the muscle, mucous and submucous layer. These processes can lead to host fish malnutrition and anemia (Gaines et al., 2012; Rivadeneyra et al., 2020). Infections by P. (S.) inopinatus can affect both wild and farmed fish populations (Takemoto et al., 2009; Kohn et al., 2011; Gaines et al., 2012).

In Brazil, P. (S.) inopinatus has been reported infecting several fish species in the Paraná River system (Takemoto et al., 2009; Kohn et al., 2011) and Amazon River system (Gonçalves et al., 2016; Hoshino et al., 2016; Fujimoto et al., 2018; Ferreira et al., 2019), but only a few of these studies have addressed the interactions of the host-parasite system. Vicente et al. (1985) listed 21 species of freshwater fish infected by $P$. (S.) inopinatus. Subsequently, Luque et al. (2011) listed 56 species of freshwater fish infected by this nematode species. Despite this knowledge about $P$. (S.) inopinatus, its patterns in fish in Brazil remain unknown.

Studies on ecological patterns and parasite distribution should be the second step in seeking to understand the patterns and processes of parasitic infections in wild fish populations. The first step is the determination of infection rates of the parasite species in the host fish populations (Chemes \& Takemoto, 2020). Considering the complexity and diversity of the different Brazilian aquatic ecosystems, which are occupied by different species of fish, these investigations need to be conducted in order to better understand the factors that determine these patterns and processes for the different species of parasites, including the nematode $P$. (S.) inopinatus. In addition, these studies 
are also important because many aquatic ecosystems are threatened; thus, for many species of parasites, there is a potential risk of extinction. Thus, the aim of the present study was to investigate the patterns and distribution of $P$. (S.) inopinatus in freshwater teleost fish in Brazil. Our hypothesis was that for different host fish species with different life histories and geographic distributions across Brazilian hydrographic basins, the infection parameters (prevalence, intensity and abundance) and parasite-host interactions vary according to trophic level of hosts.

\section{Materials and Methods}

A review on $P$. (S.) inopinatus in freshwater teleost fish in Brazil was carried out using searches in different databases (SciELO, ISI, Scopus, Science Direct, Zoological Records, CAB Abstracts Lilacs, Periódico Capes and Google Scholar). Data from 88 available scientific papers were used. A data set on P. (S.) inopinatus in freshwater fish populations in Brazil was compiled using taxonomic descriptions and surveys of occurrences and infection parameters of this nematode that were published between 1928 and 2019. These data included research on $P$. (S.) inopinatus in native fish species in rivers, lakes, ponds and reservoirs across Brazil, with the exception of three samples (two relating to Colossoma macropomum Cuvier, 1818 and one to the hybrid C. macropomum x Piaractus brachypomus Cuvier, 1818 from cultivation. No statistical comparison was carried out between the samples of parasites of wild fish $(N=177)$ and aquaculture fish $(N=4)$, since the majority of the samples were from wild fish populations. All of these surveys were chosen because they represented the various ecosystems found in Brazil and, therefore, would be able to help answer the main questions of this study about the pattern and distribution of $P$. (S.) inopinatus in freshwater fish across Brazil. The systematic classification used for fish species was based on Froese \& Pauly (2019).

The trophic level for each species of host fish was obtained from Froese \& Pauly (2019). Each sampling unit was defined as a number of individuals parasitized by $P$. (S.) inopinatus at a given site. The data were organized in a spreadsheet (".xl") with a list of the following variables: (i) number of fish examined, (ii) number of parasitized fish, (iii) infection site in the host fish, (iv) mean prevalence, (v) mean intensity and (vi) mean abundance. The following category factors were also used: (i) host fish species, (ii) trophic level of the host fish (herbivorous, detritivorous, omnivorous, carnivorous or piscivorous) and (iii) collection site of each sample (Supplementary Material - S1). These variables and factors were analyzed in order to produce a classification of patterns for $P$. (S.) inopinatus, using the R software with the "bipartite package" (Dormann et al., 2008; Dormann, 2011; R Development Core Team, 2017) or similarities for the variables. In addition, aggregation distribution pattern, correlation of abundance with body size (length and weight) of host fish and association with other endoparasite infracommunities in the hosts were investigated. No studies with inconsistent or discrepant data relating to the host and/or parasite (e.g. host infection site and/or host fish collection site) were included in the data analyses. To produce a map showing the geographic distribution of $P$. (S.) inopinatus across Brazil, the seven largest continental river basin systems in the country were taken into account (ANA, 2020).

\section{Statistical analyses}

Data on the mean prevalence, mean intensity and mean abundance that were available in scientific papers were used to characterize the parameters of infection, as recommended by Bush et al. (1997). These data were firstly evaluated with regard to assumptions of normal distribution and homoscedasticity using the Shapiro-Wilk and Bartlett tests, respectively. Since these data were found not to present normal distribution, the Kruskal-Wallis test was then used, to compare medians between the trophic levels (i.e. detritivorous, omnivorous, carnivorous and piscivorous) of the host fish and multiple comparisons performed by Dunn's test, with Bonferroni correction of significance level (Zar, 2010).

To evaluate similarities between the trophic levels of the hosts, a data matrix was constructed using the abundance of $P$. (S.) inopinatus for the population of fish. The data matrix was subjected to cluster analysis using the Bray-Curtis index (Krebs, 1999), to test the null hypothesis of no difference in the composition of parasite communities between host fish, using the R software. Non-metric multidimensional scaling (NMDS) with Bray-Curtis similarity distances was also performed using abundance data on $P$. (S.) inopinatus for populations of detritivorous, omnivorous, carnivorous and piscivorous hosts, with the aim of evaluating the general pattern of similarity between these host fish. In this analysis, we used the R statistical environment (R Development Core Team, 2017) and the "Vegan" library (Oksanen et al., 2017).

\section{Results}

A total of 181 samples of $P$. (S.) inopinatus in 81 species of freshwater fish at different trophic levels and one sample of tambatinga hybrid (C. macropomum $\times$ P. brachypomus) were analyzed. The host fish belonged to 19 families in five orders and were infected at different sites (Table 1). 
Table 1. Species of freshwater fish ( $\mathrm{N}=81)$ from the Brazil infected by Procamallanus (Spirocamallanus) inopinatus, infection sites and trophic levels of hosts.

\begin{tabular}{|c|c|c|c|c|}
\hline Orders & Families & Host species & Trophic level* & Infection sites \\
\hline \multirow[t]{56}{*}{ Characiformes } & Bryconidae & Brycon amazonicus Spix \& Agassiz, 1829 & Omnivorous & Intestine \\
\hline & & Brycon melanopterus Cope, 1872 & Omnivorous & Intestine \\
\hline & & Brycon hilarii Valenciennes, 1850 & Omnivorous & Intestine and caecum pyloric \\
\hline & & Brycon orthotaenia Günther, 1864 & Omnivorous & Intestine \\
\hline & & Salminus brasiliensis Cuvier, 1816 & Omnivorous & Stomach and intestine \\
\hline & & Brycon falcatus Müller \& Troschel, 1844 & Omnivorous & Intestine \\
\hline & & Brycon orbignyanus Valenciennes, 1850 & Omnivorous & Mesentery \\
\hline & Erythrinidae & Hoplerythrinus unitaeniatus Spix \& Agassiz, 1829 & Carnivorous & $\begin{array}{c}\text { Intestine, abdominal cavity, caecum } \\
\text { pyloric and stomach }\end{array}$ \\
\hline & & Hoplias malabaricus Bloch, 1794 & Carnivorous & $\begin{array}{l}\text { Intestine, abdominal cavity, caecum } \\
\text { pyloric and stomach }\end{array}$ \\
\hline & Acestrorhynchidae & Acestrorhynchus lacustris Lütken, 1875 & Piscivorous & Intestine \\
\hline & & Acestrorhynchu falcatus Bloch, 1794 & Piscivorous & Intestine \\
\hline & & Acestrorhynchus falcirostris Cuvier, 1819 & Piscivorous & Intestine \\
\hline & Anostomidae & Leporinus sp. & Omnivorous & Intestine \\
\hline & & Leporinus copelandii Steindachner, 1875 & Omnivorous & Intestine \\
\hline & & Schizodon nasutus Kner, 1858 & Herbivorous & Intestine \\
\hline & & Schizodon borelli Boulenger, 1900 & Herbivorous & Intestine \\
\hline & & Leporinus elongatus Valenciennes, 1850 & Omnivorous & Intestine and caecum pyloric \\
\hline & & Leporinus fasciatus Bloch, 1794 & Omnivorous & Intestine \\
\hline & & Leporinus striatus Kner, 1858 & Omnivorous & Intestine \\
\hline & & Leporinus macrocephalus Garavello \& Britski, 1988 & Omnivorous & Intestine \\
\hline & & Leporinus obtusidens Valenciennes, 1837 & Omnivorous & Intestine and caecum pyloric \\
\hline & & Leporinus friderici Bloch, 1794 & Omnivorous & $\begin{array}{l}\text { Intestine, caecum pyloric, mesentery } \\
\text { and stomach }\end{array}$ \\
\hline & & Leporinus lacustris AmaralCampos, 1945 & Omnivorous & Intestine and caecum pyloric \\
\hline & & Leporinus taeniatus Lütken, 1875 & Omnivorous & $\begin{array}{l}\text { Intestine, caecum pyloric and } \\
\text { stomach }\end{array}$ \\
\hline & & Leporinus piau Fowler, 1941 & Omnivorous & $\begin{array}{l}\text { Intestine, caecum pyloric and } \\
\text { stomach }\end{array}$ \\
\hline & & Leporinus reinhardti Lütken, 1875 & Omnivorous & $\begin{array}{l}\text { Intestine, caecum pyloric and } \\
\text { stomach }\end{array}$ \\
\hline & & Schizodon knerii Steindachner, 1875 & Omnivorous & $\begin{array}{l}\text { Intestine, caecum pyloric and } \\
\text { stomach }\end{array}$ \\
\hline & & Leporellus vittatus Valenciennes, 1850 & Omnivorous & $\begin{array}{l}\text { Intestine, caecum pyloric and } \\
\text { stomach }\end{array}$ \\
\hline & Characidae & Astyanax lacustris Lütken, 1875 & Omnivorous & $\begin{array}{l}\text { Intestine, caecum pyloric and } \\
\text { stomach }\end{array}$ \\
\hline & & Astyanax fasciatus Cuvier, 1819 & Omnivorous & Intestine \\
\hline & & Astyanax sp. & Omnivorous & Intestine \\
\hline & & Astyanax paranae Eigenmann, 1914 & Omnivorous & Intestine \\
\hline & & Galeocharax humeralis Valenciennes, 1834 & Omnivorous & Intestine \\
\hline & & Astyanax schubarti Britski, 1964 & Omnivorous & Intestine \\
\hline & & Hyphessobrycon takasei Géry, 1964 & Omnivorous & Intestine \\
\hline & & Hemibrycon surinamensis Géry, 1962 & Omnivorous & - \\
\hline & & Cynopotamus kincaidi Schultz, 1950 & Carnivorous & - \\
\hline & Serrasalmidae & Pygocentrus nattereri Kner, 1858 & Piscivorous & Intestine and caecum pyloric \\
\hline & & Pygocentrus sp. & Piscivorous & Intestine \\
\hline & & Serrasalmus spilopleura Kner, 1858 & Piscivorous & Intestine \\
\hline & & Serrasalmus marginatus, Valenciennes, 1837 & Piscivorous & Intestine and caecum pyloric \\
\hline & & Serrasalmus maculatus Kner, 1858 & Piscivorous & Caecum pyloric \\
\hline & & Serrasalmus altispinis Merckx, Jégu \& Santos, 2000 & Piscivorous & - \\
\hline & & Serrasalmus brandtii Lütken, 1875 & Piscivorous & $\begin{array}{l}\text { Intestine, caecum pyloric and } \\
\text { stomach }\end{array}$ \\
\hline & & Myloplus asterias Müller \& Troschel, 1844 & Carnivorous & Intestine \\
\hline & & Metynnis lippincottianus Cope, 1870 & Carnivorous & Intestine, and stomach \\
\hline & & Metynnis hypsauchen Müller \& Troschel, 1844 & Carnivorous & $\begin{array}{l}\text { Intestine, caecum pyloric and } \\
\text { stomach }\end{array}$ \\
\hline & & Colossoma macropomum Cuvier, 1816 & Carnivorous & $\begin{array}{l}\text { Intestine, caecum pyloric and } \\
\text { stomach }\end{array}$ \\
\hline & & Mylossoma duriventre Cuvier, 1818 & Carnivorous & Caecum pyloric \\
\hline & Cynodontidae & Rhaphiodon vulpinus Spix \& Agassiz, 1829 & Carnivorous & - \\
\hline & Iguanodectidae & Bryconops melanurus Bloch, 1794 & Omnivorous & $\begin{array}{l}\text { Intestine, caecum pyloric and } \\
\text { stomach }\end{array}$ \\
\hline & Prochilodontidae & Semaprochilodus insignis jardine, 1841 & Detritivorous & Intestine \\
\hline & & Prochilodus lineatus Valenciennes, 1837 & Detritivorous & Intestine \\
\hline & Triportheidae & Triportheu rotundatus jardine, 1841 & Omnivorous & Intestine and abdominal cavity \\
\hline & & Triportheus angulatus Spix \& Agassiz, 1829 & Omnivorous & Intestine, caecum pyloric and liver \\
\hline & & Triportheus curtus Garman, 1890 & Omnivorous & $\begin{array}{l}\text { Intestine, caecum pyloric and } \\
\text { stomach }\end{array}$ \\
\hline
\end{tabular}


Table 1. Continued...

\begin{tabular}{|c|c|c|c|c|}
\hline Orders & Families & Host species & Trophic level* & Infection sites \\
\hline \multirow[t]{23}{*}{ Siluriformes } & Loricariidae & Squaliforma emarginata Valenciennes, 1840 & Detritivorous & - \\
\hline & & Loricaria prolixa Isbrücker \& Nijssen, 1978 & Detritivorous & Intestine \\
\hline & Auchenipteridae & Trachelyopterus galeatus Linnaeus, 1766 & Omnivorous & - \\
\hline & & Auchenipterus nuchalis Spix \& Agassiz, 1829 & Carnivorous & - \\
\hline & Callichthyidae & Corydoras melanistius Regan, 1912 & Omnivorous & Intestine \\
\hline & & Corydoras spilurus Norman, 1926 & Omnivorous & Intestine \\
\hline & & Corydoras amapaenses Nijssen, 1972 & Omnivorous & Intestine \\
\hline & & Corydoras ephippifer Nijssen, 1972 & Omnivorous & Intestine \\
\hline & Pimelodidae & Pimelodus sp. & Omnivorous & - \\
\hline & & Pimelodus maculatus Lacepède, 1803 & Omnivorous & - \\
\hline & & Calophysis macropterus Lichtenstein, 1819 & Omnivorous & Intestine \\
\hline & & Zungaro zungaro Humboldt, 1821 & Piscivorous & Intestine \\
\hline & & Pseudoplatystoma corruscans Spix \& Agassiz, 1829 & Piscivorous & Intestine \\
\hline & & Pseudoplatystoma punctifer Castelnau, 1855 & Piscivorous & - \\
\hline & Doradidae & Pterodoras granulosus Valenciennes, 1821 & Omnivorous & Intestine \\
\hline & & Trachydoras paraguayensis Eigenmann \& Ward, 1907 & Omnivorous & Intestine \\
\hline & & Geophagus brasiliensis Quoy \& Gaimard, 1824 & Omnivorous & - \\
\hline & & Cichlasoma amazonarum Kullander, 1983 & Omnivorous & Intestine \\
\hline & & Cichlasoma bimaculatum Linnaeus, 1758 & Omnivorous & Intestine \\
\hline & & Astronotus ocellatus Agassiz, 1831 & Omnivorous & Intestine \\
\hline & & Crenicichla haroldoi Luengo \& Britski, 1974 & Piscivorous & Intestine \\
\hline & & Cichla kelberi Kullander \& Ferreira, 2006 & Piscivorous & Intestine \\
\hline & & Cichla ocellaris Bloch \& Schneider, 1801 & Piscivorous & Intestine and stomach \\
\hline Osteoglossiformes & Arapaimidae & Arapaima gigas Schinz, 1822 & Piscivorous & Intestine \\
\hline Pleuronectiformes & Achiridae & Catathyridium jenynsii Günther, 1862 & Piscivorous & - \\
\hline
\end{tabular}

*Based on Froese \& Pauly (2019).

Table 2. Parameters of infection by Procamallanus (Spirocamallanus) inopinatus in samples with 50 species of freshwater fish in Brazil.

\begin{tabular}{ccccccc}
\hline Parameters & $\mathbf{N}$ & Median & $\mathbf{2 5}^{\text {th }}$ percentile & 75 $^{\text {th }}$ percentile & Minimum & Maximum \\
\hline Prevalence (\%) & 87 & 21.2 & 8.9 & 39.3 & 0.04 & 100 \\
Intensity & 76 & 1.8 & 1.3 & 3.0 & 0.06 & 411.1 \\
Abundance & 81 & 0.4 & 0.1 & 1.1 & 0.01 & 411.1 \\
\hline
\end{tabular}

$\mathrm{N}$ : Sample number.

The prevalence, intensity, and abundance of $P$. (S.) inopinatus in the host fish samples analyzed are shown in Figure 1 and Table 2. The prevalence was greater than or equal to 40\% in some species: Leporinus friderici Bloch, 1794; Leporinus obtusidens Valenciennes, 1837 and Leporinus macrocephalus Garavello \& Britski, 1988 (Anostomidae); Astyanax lacustris Lütken, 1875; Metynnis lippincottianus Cope 1780; Metynnis hypsauchen Müller \& Troschel, 1844 and Hyphessobrycon takasei Géry, 1964 (Characidae); Auchenipterus nuchalis Spix \& Agassiz, 1829 (Auchenipteridae); Bryconops melanurus Bloch, 1794 (Iguanodectidae); Triportheus rotundatus Jardine, 1841 (Triportheidae); Hoplerythrinus unitaeniatus Spix \& Agassiz, 1829 (Erythrinidae); Pygocentrus nattereri Kner, 1858 and Serrasalmus altispinis Merckx, Jégu \& Santos, 2000 (Serrasalmidae); and Corydoras ephippifer Nijssen, 1972, Corydoras amapaensis Nijssen, 1972 and Corydoras spilurus Norman, 1926 (Callichthyidae). However, most host fish had low prevalence, low intensity and low abundance of $P$. (S.) inopinatus.

In the host fish samples, the intensity and abundance of $P$. (S.) inopinatus were similar $(p>0.05)$ according to trophic levels, since the numbers of samples from detritivorous $(N=4)$, carnivorous $(N=10)$, omnivorous $(N=52)$ and piscivorous $(N=19)$ fish hosts were low, while omnibus test showed that the prevalence between detritivorous, carnivorous, omnivorous and piscivorous had some difference $(p=0.027)$, identified with Dunn's test (Figure 2).

The Bray-Curtis cluster analysis between the host fish species showed a co-phenetic coefficient of 0.960 with 1,000 permutations. The results showed that there were three well-defined clusters. The first group included detritivorous hosts (Semaprochilodus insignis Jardine, 1841; Squaliforma emarginata Valenciennes, 1840; Loricaria prolixa Isbrücker \& Nijssen, 1978 and Prochilodus lineatus Valenciennes, 1837), omnivorous hosts (A. nuchalis) and carnivorous hosts (H. unitaeniatus, Hoplias malabaricus Bloch, 1794; Rhaphiodon vulpinus Spix \& Agassiz, 1829 and Salminus brasiliensis Cuvier, 1816). The second cluster only included omnivorous hosts and the third cluster only included only piscivorous hosts, with higher similarity (Figure 3). 

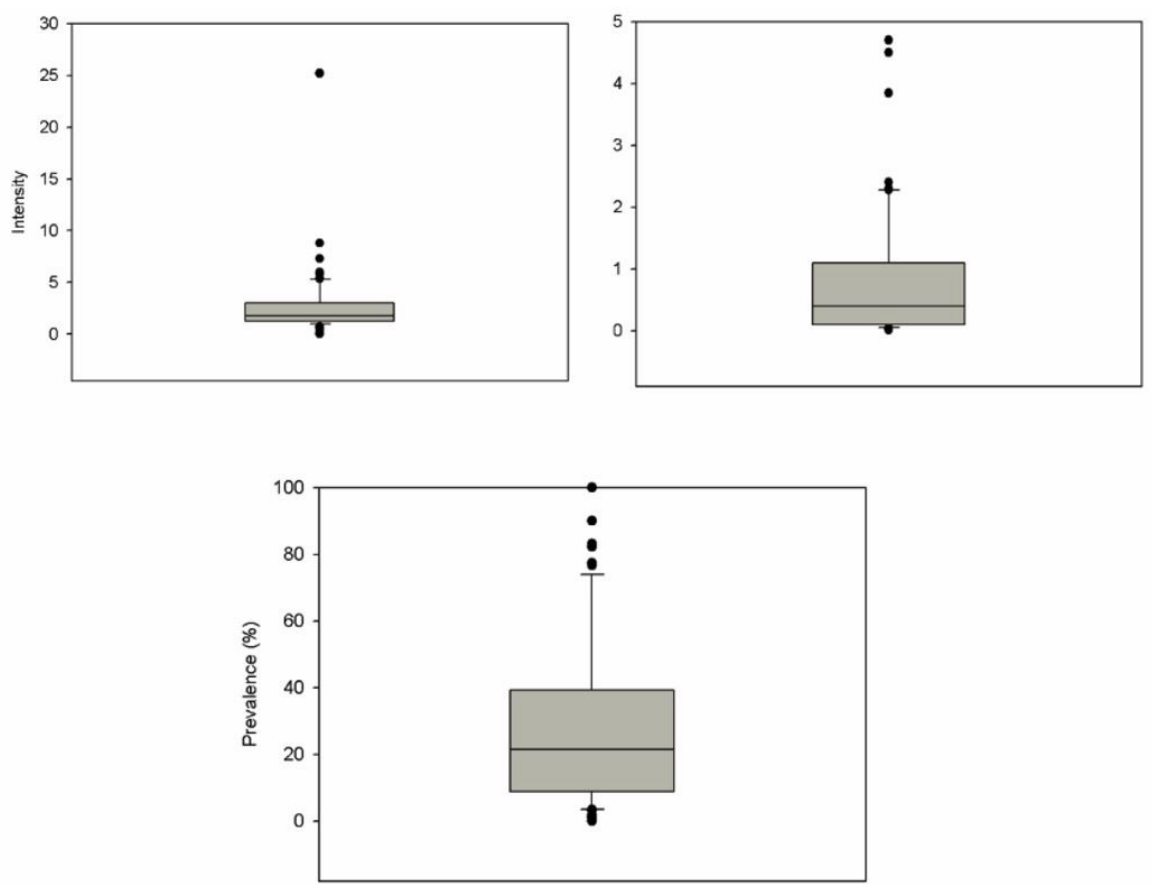

Figure 1. Quantitative descriptors of infection by Procamallanus (Spirocamallanus) inopinatus in 87 samples with 50 species of freshwater fish in Brazil (Box plots represent medians, interquartile ranges 25-75\%, minimum-maximum values and outliers).

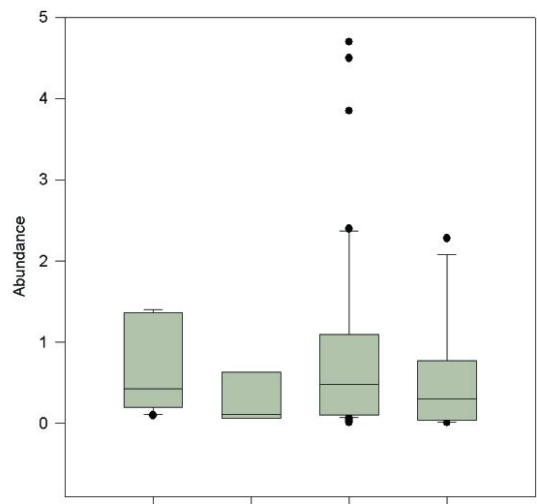

Carnivorous Detritivorous Omnivorous Piscivorous

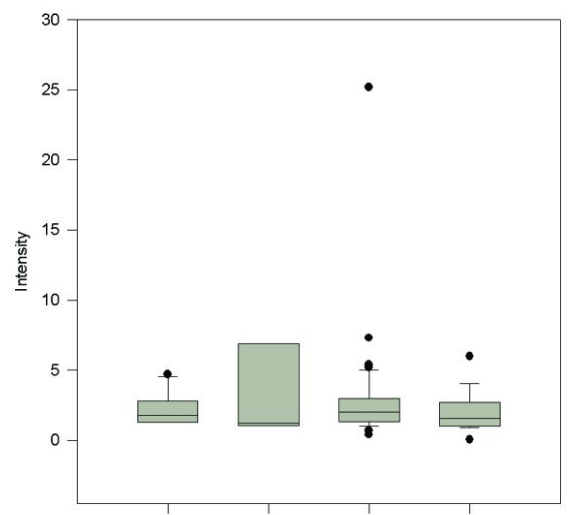

Carnivorous Detritivorous Omnivorous Piscivorous

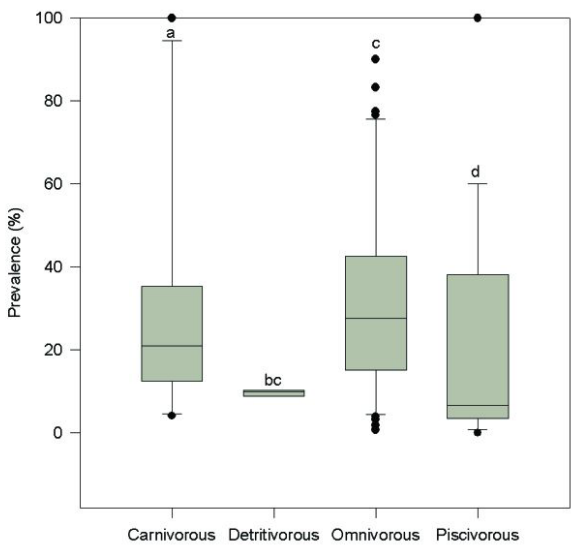

Figure 2. Quantitative descriptors of infection by Procamallanus (Spirocamallanus) inopinatus in 85 samples with 50 species of freshwater fish in Brazil, according to the trophic level of the hosts (Box plots represent medians, interquartile ranges 25-75\%, minimum values and outliers). Kruskal-Wallis test for prevalence $(H=1.283, g l=3, p=0.005)$ indicate differences among trophic levels of hosts. Different letters indicate differences between trophic level for prevalence according to Dunn test $(p=0.027)$. There was no difference among trophic levels of hosts according to Kruskal-Wallis test for intensity $(H=2.068, g l=3, p=0.558)$ and abundance $(\mathrm{H}=4.619, \mathrm{gl}=3, \mathrm{p}=0.202)$. 


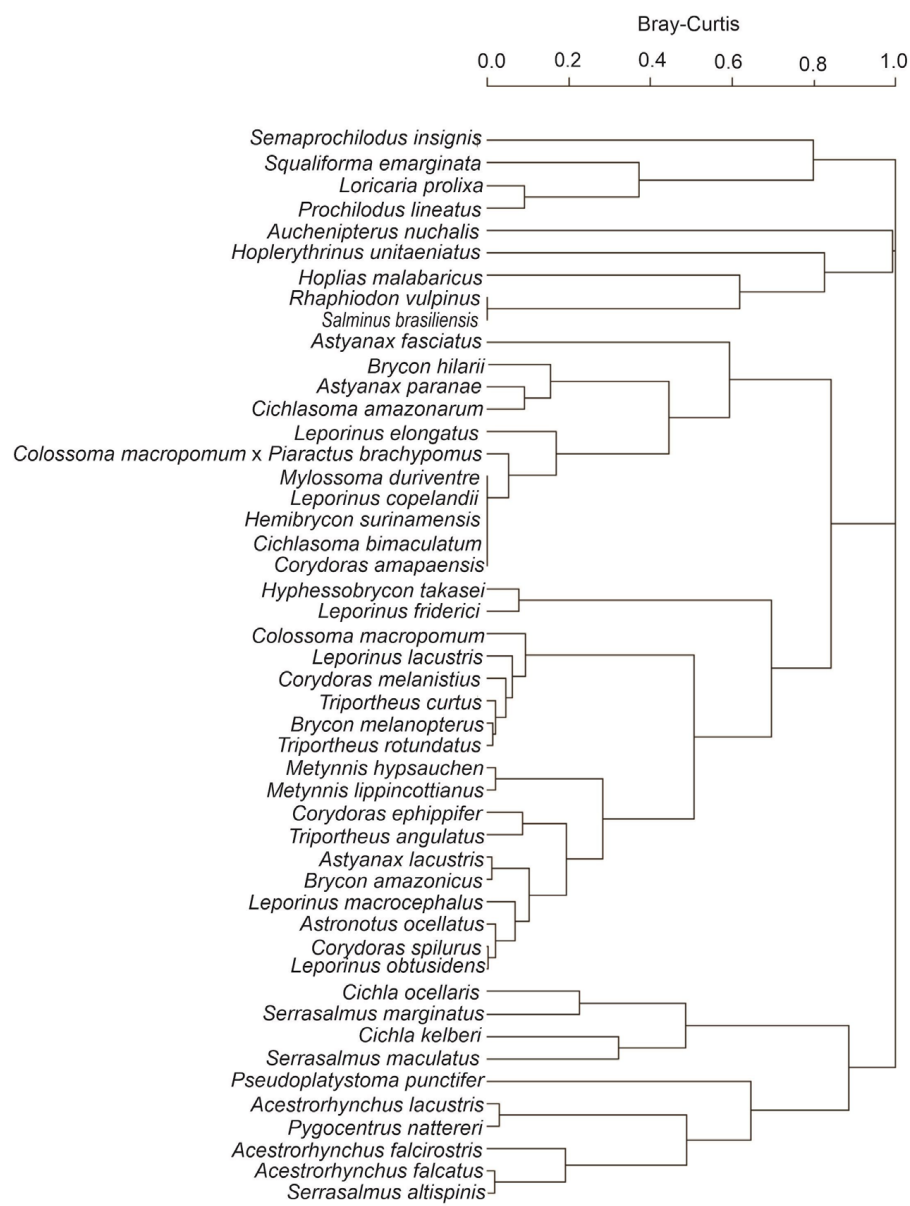

Figure 3. Dendogram of Bray-Curtis similarity for the community of Procamallanus (Spirocamallanus) inopinatus in 87 samples with 48 freshwater fish species in Brazil.

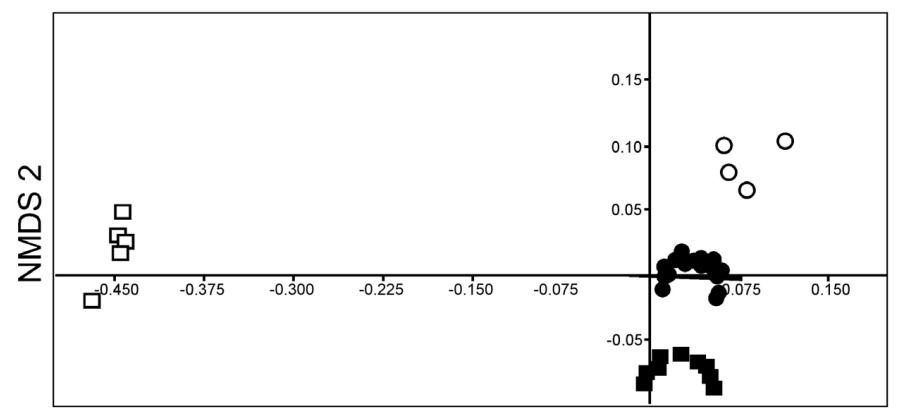

NMDS 1

Figure 4. Non-metric multidimensional scaling (NMDS) for the abundance of Procamallanus (Spirocamallanus) inopinatus in 4 samples of detritivorous ( $\square$ ), 52 samples of omnivorous (0), 10 samples of carnivorous $(O)$ and 16 samples of piscivorous ( $\square$ ) host fish populations of freshwater in Brazil.

The NMDS analysis indicated that there was no difference in the abundance of $P$. (S.) inopinatus between detritivorous, omnivorous, carnivorous and piscivorous hosts (stress $=0.440$ ). There was a high stress value in relation to the number of axes (Figure 4), although a distinct separation between the hosts at these four trophic levels could be seen.

The geographic distribution of $P$. (S.) inopinatus was observed to encompass the basin systems of the Amazon River, Paraná River, São Francisco River, North Atlantic and South and East Atlantic, but there were no reports of this parasite in the basins of the Tocantins River and Uruguay River (Figure 5). 


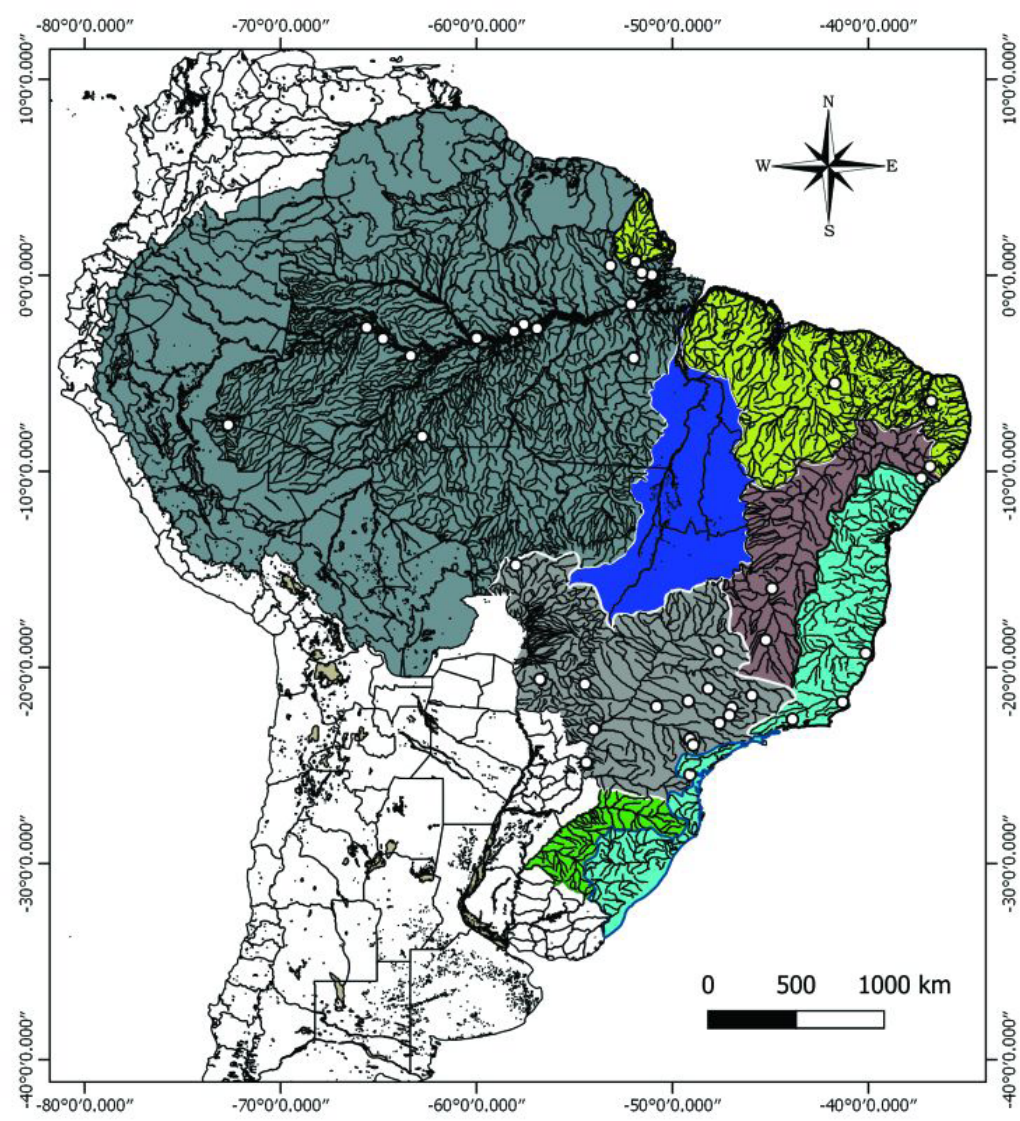

\begin{tabular}{|l|}
\hline Legend \\
$\circ$ Procamallanus (S.) inopinatus \\
\hline Hydrographic Basins \\
$\square$ Amazon river basin \\
$\square$ East and South Atlantic basins \\
$\square$ North Atlantic basins \\
Paraná river basin \\
São Francisco river basin \\
Tocantins river basin \\
$\square$ Uruguay river basin
\end{tabular}

Figure 5. Geographic distribution of Procamallanus (Spirocamallanus) inopinatus in host fish of hydrographic basin systems from the Brazil.

\section{Discussion}

\section{Distribution pattern of host-parasite interaction}

In this study, we carried out a search for patterns of infection by $P$. (S.) inopinatus and distribution parameters in 82 host fish in 19 families and five orders in Brazil, which were mainly species of Characiformes (71.6\%), Erythrinidae (20.9\%), Serrasalmidae (14.8\%) and Characidae (11.1\%). Characiformes accounts for around $75 \%$ of freshwater fish in the Neotropical region, with approximately 234 genera and 2,000 species, distributed in different families at different trophic levels, including herbivorous, omnivorous and piscivorous species, which ingest a wide variety of food items and range from generalists to specialists, due to their differing body sizes (Bonato et al., 2017; Froese \& Pauly, 2019). Therefore, these results may reflect greater effort on studies on the parasites of these host fish taxa and may also reflect local priorities for parasitological research on these host fish taxa. Nonetheless, despite these studies on the presence and infection of $P$. (S.) inopinatus in freshwater fish in different Brazilian aquatic systems, the distribution patterns were unknown until now.

We detected the following patterns within P. (S.) inopinatus-host interactions in the different basins in Brazil: (a) prevalence ranging from low to moderate, with low abundance and low intensity; (b) distribution pattern typically aggregated and occasionally random; (c) positive or negative correlation of abundance with body size (length and weight) of host fish at the infracommunity level; and (d) association with other endoparasite infracommunities at different infection sites in the hosts, mostly in the intestine and stomach. In these host fish, occurrences of $P$. (S.) inopinatus together with other endoparasite infracommunities and occupation of different infection sites (e.g. intestine, stomach, pyloric caecum and abdominal cavity) in the same population of fish, with different levels of infection together and with an aggregated dispersion pattern, seems allow coexistence of parasite species that would be excluded. Therefore, these findings corroborate the suggestion that the levels of different parasites 
shared by the same host may favor coexistence of more species of parasites, since large phylogenetic differences allow potentially competing parasites to consume the same resources without being sensitive to other parasite species (Geets \& Ollevier, 1996; Bellay et al., 2013; Bhuiyan et al., 2014; Salgado-Maldonado et al., 2016, 2019). The findings from the present study are in line with this, because in most of the parasite-host systems investigated here, the gastrointestinal tract was the site most frequently infected by $P$. (S.) inopinatus.

In the samples of freshwater host fish from Brazil that we analyzed, we found low prevalence, low abundance and low intensity of abundance of $P$. (S.) inopinatus. This low parasitism level may be attributed, in part, to the fact that this nematode has a complex life cycle, with transmission through prey-predator interactions. Thus, the presence or absence of copepods (intermediate hosts), containing infective stages of $P$. (S.) inopinatus in different environments, determines the levels of their infection in populations of definitive hosts, i.e. the fish species. In addition, variations in the levels of endohelminth infection are, in general, strongly dependent on the population densities of intermediate and definitive hosts, overlapping in time and space in the same ecosystem (BlascoCosta et al., 2015). It is also important to highlight that we analyzed host fish from different Brazilian hydrographic basin systems, which are environments with different dynamics due to the diverse characteristics of their water (Agostinho et al., 2005; Brasil, 2006; Takemoto et al., 2009; Barletta et al., 2010; Carvalho \& Albert, 2011; Junk, 2013; $\mathrm{Val}, 2019)$. These characteristics strongly influence the invertebrate and fish communities that are intermediate and definitive hosts for $P$. (S.) inopinatus, respectively. In addition, accessibility to the definitive hosts is also related to the evolutionary strategies of endohelminths, given that some species in the adult stage are more dependent on the particular characteristics of the host fish (Bellay et al., 2013). Nevertheless, $P$. (S.) inopinatus is a species of camallanid whose strategies and life history were little known until now.

Several studies on wild fish populations have emphasized the importance of the hosts' diet and trophic level in relation to the diversity and parameters of endohelminth parasite infections (Choudhury \& Dick, 2000; Simková et al., 2001; Timi et al., 2011; Poulin \& Leung, 2011; Gonçalves et al., 2016; Hoshino et al., 2016; Ferreira et al., 2019; Baia et al., 2018; Negreiros et al., 2019; Ferreira et al., 2019). Endohelminth larvae complete their life cycles when ingested by their definitive hosts and are therefore dependent on prey-predator interactions (Choudhury \& Dick, 2000; Timi et al., 2011; Poulin \& Leung, 2011; Bhuiyan et al., 2014; Gonçalves et al., 2016; Hoshino et al., 2016; Baia et al., 2018). For this reason, fish at higher trophic levels (e.g. carnivorous and piscivorous fish) are exposed to higher numbers of infective endohelminth larvae than are those at lower trophic levels (e.g. insectivorous, herbivorous, detritivorous and omnivorous fish). The latter have lower richness and abundance of these parasites (Geets \& Ollevier, 1996; Choudhury \& Dick, 2000; Simková et al., 2001; Timi et al., 2011; Gonçalves et al., 2016). In the parasite-host systems investigated here, cluster analysis (Bray-Curtis) showed that host fish at the same trophic level had well-defined groups with high similarity. Consequently, the intensity and abundance of $P$. (S.) inopinatus were also similar for detritivorous, omnivorous, carnivorous and piscivorous hosts, influenced by the low levels of parasitic infection and predominant sampling of omnivorous hosts. However, the prevalence was higher in omnivorous hosts following by carnivorous hosts. In contrast, in a study on an assemblage of host fish in the lgarapé Fortaleza basin, a tributary of the Amazon River in Brazil, the prevalence of endohelminths in detritivorous hosts was reported to be lower than in carnivorous, omnivorous and piscivorous hosts, while the intensity and abundance were higher in carnivorous and omnivorous hosts (Baia et al., 2018). It has also been shown that the richness of endoparasite species in carnivorous fish is higher than in herbivorous fish (Simková et al., 2001). Choudhury \& Dick (2000) reported that herbivorous fish had poorer endohelminth communities than benthivorous fish that feed on invertebrates. Moreover, the endohelminth communities in planktivorous and benthivorous fish were qualitatively different, since in planktivorous hosts the community was dominated by cestode species and in benthivorous fish by trematode species. These patterns were correlated with differences in the transmission strategies of these parasite taxa. Additionally, these authors found that carnivorous fish with diets based on invertebrates and fish and omnivorous fish with diets containing only invertebrates had higher richness of endohelminth communities than herbivorous and planktivorous fish. Therefore, these results demonstrate that omnivorous diet was a factor that was as determinant for accumulation of endoparasites as was accumulation through predation.

In the host fish analyzed, the nematode $P$. (S.) inopinatus was found in the adult stage. Since host-parasite interactions depend on mechanisms that provide parasites with a greater chance of completing their life cycle, the adaptations of generalist parasites such as $P$. (S.) inopinatus are not necessarily related to co-evolutionary processes in the parasites and hosts. They may also be related to low specificity to the intermediate hosts that are prey for the definitive hosts, i.e. the fish. Hence, in this trophic transmission system, $P$. (S.) inopinatus may have a greater chance of reaching its definitive hosts, because of its wide distribution in different host fish species (Bellay et al., 2013). 
Although the life cycle of $P$. (S.) inopinatus remains unknown, studies on Procamallanus species have shown that different copepod species are the intermediate hosts for these camallanid nematodes. After ingestion by copepods, the first-stage larvae of Procamallanus spp. penetrate the hemocele of these intermediate hosts (e.g. Mesocyclops spp. and Diaptomus spp.) and reach the infective stage. Fish (the definitive hosts) acquire the infection from camallanids through feeding on copepods containing the infective stages of these camallanids (Pereira et al., 1936; De, 1995; Moravec et al., 1995; De \& Maity, 2000).

In Brazil, it has been reported that the biological cycle of Procamallanus (Spirocamallanus) hilarii Vaz \& Pereira, 1934 [= Procamallanus (Spirocamallanus) cearensis Pereira, Dias \& Azevedo, 1936] takes place in the copepods Diaptomus Herbst, 1955, which are the intermediate hosts, and in Astyanax lacustris Lütken, 1875, which are the definitive hosts (Pereira et al., 1936). Therefore, it is possible to suggest that in the life cycle of $P$. (S.) inopinatus, the newly-hatched larvae are released into the feces of the definitive hosts (fish) in the water and are also ingested by copepod species (e.g. Diaptomus spp.), the intermediate hosts of this nematode species. Lastly, the larvae of this nematode invade the body cavity of the copepods and develop to reach the infective stages that are ingested by a fish, thereby reaching the adult stage. Nevertheless, detailed knowledge of this association between $P$. $(S$.) inopinatus and its intermediate hosts will only become possible when its biological cycle has been completely studied in the laboratory.

\section{Geographic distribution pattern in freshwater fish in Brazil}

In ecosystems, because of the potential role played by parasites, identification of critical points with high parasite diversity and areas of relatively low diversity is crucial for understanding the functioning of the biosphere. However, parasite biodiversity estimates for any geographic area can only be carried out after the parasite species and their host species are well known (Luque \& Poulin, 2007).

As knowledge about parasite biodiversity increases, efforts towards mapping this diversity of parasites can also be developed. The aim will be to identify potential geographic hotspots for emerging diseases and to predict and mitigate the impacts of climate change on pathogen distribution. However, data limitations impede establishment of global biodiversity distribution maps for most parasite taxa (Jorge \& Poulin, 2018). Thus, currently, geographic distribution is one of the several universal issues relating to the processes and patterns of the parasite species harbored by freshwater fish harbor that need to be addressed. This has already been done in some locations and regions: for instance, in the Canary Islands (Thorsen et al., 2000), Mexico (Pérez-Ponce De León \& Choudhury, 2005), Asia, Africa and South America (Pariselle et al., 2011) and Europe (Thieltges et al., 2011).

González et al. (2006) investigated the geographic distribution of endohelminths in Sebastes capensis Gmelin, 1789, from the coasts of Peru, Chile, Argentina and South Africa. They concluded that the geographic patterns were a consequence of the biogeographic patterns exhibited by their prey, which were used as intermediate hosts. This was a determining factor in the structure of endohelminth communities throughout their distribution range. The specificity of hosts therefore strongly influences the biogeography of parasites, since there is close relationship between the hosts, as well as between them and the environment. These are determining factors in the characteristics of the regional fauna of endohelminth species (Thieltges et al., 2011; Salgado-Maldonado et al., 2016).

In Brazil, the geographic patterns of parasite distribution in freshwater fish have been little reported. TavaresDias et al. (2015) studied these patterns in relation to species of Crustacea in 119 hosts within 27 families in eight orders, distributed across the different Brazilian hydrographic basins. Pinheiro et al. (2019) reported on the geographic patterns of larvae of Contracaecum Railliet \& Henry, 1912, among 140 fish species within 49 families in 16 orders. The geographic patterns of parasite species among 45 Loricariidae species were studied by Borges et al. (2018). Valladão et al. (2019) reported on the geographic patterns of Neoechinorhynchus buttnerae Golvan, 1956, in C. macropomum, across this country. Information of this nature is useful for gaining greater understanding of the biodiversity and geographic distribution patterns of host-parasite systems. However, many questions remain to be answered regarding the distribution patterns of the most abundant Nematoda taxa in fish, across Brazil.

The distribution patterns of endohelminth species result from several factors. In addition to physiographic changes and differences in habitats, the biology of these parasites can vary between species. Most parasites are closely associated with their hosts, through sharing their co-evolution history, and their biogeographic distribution generally reflects that of their hosts. Ecological factors also influence the parasite's biogeography, mostly regarding the local diversity of the parasite communities. However, the co-evolution link between parasites and their hosts is a more important factor in this relationship (Poulin \& Mouillot, 2003). Therefore, among biological factors, host 
specificity is also a determining factor for endohelminth species, which strongly influences the characteristics of the regional endohelminth fauna.

Given that $P$. (S.) inopinatus has low specificity to hosts and high adaptability to different freshwater habitats in Brazil, this nematode species has wide geographic distribution in the basin systems of the Amazon River, Paraná River, São Francisco River and North, South and East Atlantic (Figure 5). These results also suggest that the intermediate hosts of $P$. (S.) inopinatus have wide geographic distribution in these hydrographic basin systems. This is a prerequisite for establishment of this parasitic nematode in different environments. Parasites like $P$. (S.) inopinatus, which infect a wide range of host fish in the hydrographic basin systems of Brazil, are strongly resistant to environmental changes, which thus increases their chances of expanding their geographic distribution and use of resources (Poulin, 1992; Blasco-Costa et al., 2015). Furthermore, we have identified areas with the greatest deficit in sample effort for description in occurrence of $P$. (S.) inopinatus; hence, such information provides clear guides for a better allocation of future research effort this toward $P$. (S.) inopinatus prospecting across Brazilian basins.

In conclusion, the present study on $P$. (S.) inopinatus supports the understanding of the patterns and processes of infections caused by this endoparasite that is widely distributed in Brazilian host fish populations. It therefore fills a gap in the knowledge of this nematode species. In the parasite-host interaction network, there was no link with any trophic level occupied by the host fish. Thus, analysis on greater quantities of samples is required in order to reach more conclusive results in this regard. Procamallanus (S.) inopinatus uses a wide variety of fish as definitive hosts to complete its biological cycle, and thus has a wide distribution in the hydrographic ecosystems of Brazil. However, in the basin systems of the Tocantins River and Uruguay River, the lack of occurrence of $P$. (S.) inopinatus was caused by the lack of studies. Therefore, a concentrated and focused sampling effort is required in order to elicit information that has been neglected. Hence, we believe that the diversity of host fish used by $P$. (S.) inopinatus is much greater and with wider geographic range than what is documented here. Lastly, since this information is needed in order to understand the geographic distribution capacity of $P$. (S.) inopinatus and the parasite-host relationship, we highlight that further studies are required, for greater knowledge about this nematode species in Brazilian fish to be obtained.

\section{Acknowledgements}

The authors thank the National Council for Scientific and Technological Development (Conselho Nacional de Desenvolvimento Científico e Tecnológico, CNPq), Brazil for the research productivity grant to M. Tavares-Dias (Grant No 303013/2015-0).

\section{References}

Agostinho AA, Thomaz SM, Gomes LC. Conservação da biodiversidade em águas continentais do Brasil. Megadiversidade 2005; 1(1): 70-78.

Almeida-Berto MFC, Monteiro CMM, Brasil-Sato MC. Parasitic helminths of the non-native serrasalmid fish Metynnis lippincottianus from the Três Marias Reservoir, southeast Brazil. Rev Bras Parasitol Vet 2018; 27(3): 289-294. http://dx.doi.org/10.1590/s1984296120180040. PMid:30133590.

Agência Nacional de Águas - ANA. [Online]. 2020. [cited 2020 June 4]. Available from: http://hidroweb.ana.gov.br/ HidroWeb .asp? Tocltem $=4100$

Azevedo RK, Abdallah VD, Luque JL. Acanthocephala, Annelida, Arthropoda, Myxozoa, Nematoda and Platyhelminthes parasites of fishes from the Guandu river, Rio de Janeiro, Brazil. Check List 2010; 6(4): 659-667. http://dx.doi.org/10.15560/6.4.659.

Baia RRJ, Florentino AC, Silva LMA, Tavares-Dias M. Patterns of the parasite communities in a fish assemblage of a river in the Brazilian Amazon region. Acta Parasitol 2018; 63(2): 304-316. http://dx.doi.org/10.1515/ap-2018-0035. PMid:29654690.

Barletta M, Jaureguizar AJ, Baigun C, Fontoura NF, Agostinho AA, Almeida-Val VMF, et al. Fish and aquatic habitat conservation in South America: a continental overview with emphasis on Neotropical systems.J Fish Bio/ 2010; 76(9): 2118-2176. http://dx.doi. org/10.1111/j.1095-8649.2010.02684.x. PMid:20557657.

Bellay S, Oliveira EF, Almeida-Neto M, Lima DPJr, Takemoto RM, Luque JL. Developmental stage of parasites influences the structure of fish-parasite networks. PLoS One 2013; 8(10): e75710. http://dx.doi.org/10.1371/journal.pone.0075710. PMid:24124506.

Bhuiyan Al, Bushra J, Ghani O. Abundance and distribution of endoparasitic helminths in Anabas testudineus (Bloch, 1792) from a polluted beel of Bangladesh. Bangladesh J Zool 2014; 42(1): 1-10. http://dx.doi.org/10.3329/bjz.v42i1.23331. 
Blasco-Costa I, Rouco C, Poulin R. Biogeography of parasitism in freshwater fish: spatial patterns in hot spots of infection. Ecography 2015; 38(3): 301-310. http://dx.doi.org/10.1111/ecog.01020.

Bonato KO, Burress ED, Fialho CB. Dietary differentiation in relation to mouth and tooth morphology of a neotropical characid fish community. Zool Anz 2017; 267: 31-40. http://dx.doi.org/10.1016/j.jcz.2017.01.003.

Borges WF, Oliveira MSB, Santos GG, Tavares-Dias M. Parasites in Loricariidae from Brazil: checklist and new records for fish from the Brazilian Amazon. Acta Sci Biol Sci 2018; 40(1): e40621. http://dx.doi.org/10.4025/actascibiolsci.v40i1.40621.

Brasil. Ministério do Meio Ambiente, Secretaria de Recursos Hídricos - MMA. Plano Nacional de Recursos Hídricos. Panorama e estado dos recursos hídricos do Brasil. Brasília: MMA; 2006.

Bush AO, Lafferty KD, Lotz JM, Shostak AW. Parasitology meets ecology on its own terms: margolis et al. revisited. J Parasitol 1997; 83(4): 575-583. http://dx.doi.org/10.2307/3284227. PMid:9267395.

Carvalho TP, Albert JS. The Amazon-Paraguay divide. In: AlbertJS, Reis RE, editors. Historical biogeography of Neotropical freshwater fishes. London: University of California Press; 2011. p. 193-202. http://dx.doi.org/10.1525/california/9780520268685.003.0011.

Chemes SB, Takemoto RM. Diversity of parasites from middle Paraná system freshwater fishes, Argentina. Int J Biodivers Conserv $2011 ; 3(7): 249-266$.

Chemes SB, Takemoto RM. Nuevos registros de helmintos parásitos de peces Pimelodidae, en el sistema Paraná medio (Argentina). Neotrop Helminthol 2020; 14(1): 19-34. http://dx.doi.org/10.24039/rnh2020141611.

Choudhury A, Dick TA. Richness and diversity of helminth communities in tropical freshwater fishes: empirical evidence. J Biogeogr 2000; 27(4): 935-956. http://dx.doi.org/10.1046/j.1365-2699.2000.00450.x.

De NC, Maity RN. Development of Procamallanus saccobranchi (Nematoda: Camallanidae), a parasite of a freshwater fish in India. Folia Parasitol (Praha) 2000; 47(3): 216-226. http://dx.doi.org/10.14411/fp.2000.040. PMid:11104150.

De NC. On the development and life cycle of Spirocamallanus mysti (Nematoda: camalanidae). Folia Parasitol (Praha) 1995; 42(2): $135-142$

Dormann CF, Gruber B, Fründ J. Introducing the bipartite package: analysing ecological networks. R News 2008; 8(2): 8-11.

Dormann CF. How to be a specialist? Quantifying specialisation in pollination networks. New Biol 2011; 1(1): 1-20.

Ferreira MM, Passador RJ, Tavares-Dias M. Community ecology of parasites in four species of Corydoras (Callichthyidae), ornamental fish endemic to the eastern Amazon (Brazil). An Acad Bras Cienc 2019; 91(1): e20170926. http://dx.doi.org/10.1590/00013765201920170926 . PMid:30785499.

Froese R, Pauly D. FishBase. Version (12/2019) [online]. USA: FishBase; 2019 [cited 2020 June 1]. Available from: www.fishbase.org Fujimoto RY, Couto MVS, Sousa NCS, Madi RR, Eiras JC, Martins ML. Seasonality of Procamallanus (Spirocamallanus) inopinatus (Nematoda: Camallanidae) infection in Bryconops melanurus (Characiformes: Iguanodectidae). Bol Inst Pesca 2018; 44(4): 331 -338. http://dx.doi.org/10.20950/1678-2305.2018.44.4.334.

Gaines APL, Lozano LES, Viana GM, Monteiro PC, Araújo CSO. Tissue changes in the gut of Arapaima gigas (Schinz, 1822), infected by the nematode Spirocamallanus inopinatus (Travassos, 1929). Neotrop Helminthol 2012; 6(2): 147-157.

Geets A, Ollevier F. Endoparasitic helminths of the whitespotted rabbitfish (Siganus sutor (Valenciennes, 1835) of the Kenyan coast: distribution within the host population and microhabitat use. Belg J Zool 1996; 126: 21-36.

Gonçalves RA, Oliveira MSB, Neves LR, Tavares-Dias M. Seasonal pattern in parasite infracommunities of Hoplerythrinus unitaeniatus and Hoplias malabaricus (Actinopterygii: Erythrinidae) from the Brazilian Amazon. Acta Parasitol 2016; 61(1): 119-129. http:// dx.doi.org/10.1515/ap-2016-0016. PMid:26751882.

González MT, Barrientos C, Moreno CA. Biogeographical patterns in endoparasite communities of a marine fish (Sebastes capensis Gmelin) with extended range in the southern hemisphere. J Biogeogr 2006; 33(6): 1086-1095. http://dx.doi.org/10.1111/j.13652699.2006.01488.x.

Hamann MI. Population biology of Spirocamallanus inopinatus (Travassos, Artigas et Pereira, 1928) (Nematoda, Camallanidae) in Serrasalmus spilopleura Kner, 1860 (Pisces, Characidae) from Corrientes, Argentina. Res Rev Parasitol 1999; 59(1-2): 1-6.

Hoshino MDFG, Neves LR, Tavares-Dias M. Parasite communities of the predatory fish, Acestrorhynchus falcatus and Acestrorhynchus falcirostris, living in sympatry in Brazilian Amazon. Rev Bras Parasitol Vet 2016; 25(2): 207-216. http://dx.doi.org/10.1590/S198429612016038. PMid:27334822.

Jorge F, Poulin R. Poor geographical match between the distributions of host diversity and parasite discovery effort. Proc Bio/ Sci 2018; 285(1879): 20180072. http://dx.doi.org/10.1098/rspb.2018.0072. PMid:29848643.

Junk WJ. Current state of knowledge regarding South America wetlands and their future under global climate change. Aquat Sci 2013; 75(1): 113-131. http://dx.doi.org/10.1007/s00027-012-0253-8. 
Kohn A, Moravec F, Cohen SC, Canzi C, Takemoto RM, Fernandes BMM. Helminths of freshwater fishes in the reservoir of the Hydroelectric Power Station of Itaipu, Paraná, Brazil. Check List 2011; 7(5): 681-690. http://dx.doi.org/10.15560/7.5.681.

Krebs CJ. Ecological methodology. New York: Addison-Wesley Educational Publishers; 1999.

Luque JL, Aguiar JC, Vieira FM, Gibson DI, Santos CP. Checklist of Nematoda associated with the fishes of Brazil. Zootaxa 2011; 3082(1): 1-88. http://dx.doi.org/10.11646/zootaxa.3082.1.1.

Luque JL, Pereira FB, Alves PV, Oliva ME, Timi JT. Helminth parasites of South American fishes: current status and characterization as a model for studies of biodiversity. J Helminthol 2017; 91(2): 150-164. http://dx.doi.org/10.1017/S0022149X16000717. PMid:27855726.

Luque JL, Poulin R. Metazoan parasite species richness in Neotropical fishes: hotspots and the geography of biodiversity. Parasitology 2007; 134(Pt 6): 865-878. http://dx.doi.org/10.1017/S0031182007002272. PMid:17291392.

Moravec F, Mendonza- Franco E, Vargas-Vázquez J, Vivas-Rodríguez C. Studies on the development of Procamallanus (Spirocamallanus) rebecae (Nematoda: Camallanidae), a parasite of cichlid fishes in México. Folia Parasitol (Praha) 1995; 42(4): 281-292.

Moravec F, Prouza A, Royero R. Some nematodes of freshwater fishes in Venezuela. Folia Parasitol (Praha) 1997; 44(1): 33-47. PMid:9188173.

Moravec F. Nematodes of freshwater fishes of the Neotropical region. Prague: Academia; 1998.

Negreiros LP, Florentino AC, Pereira BF, Tavares-Dias M. Long-term temporal variation in the parasite community structure of metazoans of Pimelodus blochii (Pimelodidae), a catfish from the Brazilian Amazon. Parasitol Res 2019; 118(12): 3337-3347. http:// dx.doi.org/10.1007/s00436-019-06480-x. PMid:31664517.

Oksanen JF, Blanchet G, Friendly M, Kindt R, Legendre P, McGlinn D, et al. 2017. Vegan: community ecology package. R Package version 2.4-3 [online]. USA: Vegan Development Team; 2017 [cited 2017 July 10]. Available from: https://CRAN.R-project. org/ package=vegan

Pariselle A, Boeger WA, Snoeks J, Bilong Bilong CF, Morand S, Vanhove MP. The monogenean parasite fauna of cichlids: a potential tool for host biogeography. Int J Evol Biol 2011; 471480: 471480. http://dx.doi.org/10.4061/2011/471480. PMid:21869935.

Pereira C, Dias MV, Azevedo P. Biologia do nematoide “Procamallanus cearensis” n. sp. Arch Inst Biol 1936; 7: $209-226$.

Pérez-Ponce de León G, Choudhury A. Biogeography of helminth parasites of freshwater fishes in Mexico: the search for patterns and processes. J Biogeogr 2005; 32(4): 645-659. http://dx.doi.org/10.1111/j.1365-2699.2005.01218.x.

Pinheiro RHS, Furtado AP, Santos JN, Giese EG. Contracaecum larvae: morphological and morphometric retrospective analysis, biogeography and zoonotic risk in the Amazon. Rev Bras Parasitol Vet 2019; 28(1): 12-32. http://dx.doi.org/10.1590/s198429612019002. PMid:30892463.

Poulin R, Leung TLF. Body size, trophic level, and the use of fish as transmission routes by parasites. Oecologia 2011; 166(3): 731-738. http://dx.doi.org/10.1007/s00442-011-1906-3. PMid:21249395.

Poulin R, Mouillot D. Host introductions and the geography of parasite taxonomic diversity. J Biogeogr 2003; 30(6): 837-845. http://dx.doi.org/10.1046/j.1365-2699.2003.00868.x.

Poulin R. Determinants of host-specificity in parasites of freshwater fishes. Int J Parasitol 1992; 22(6): 753-758. http://dx.doi. org/10.1016/0020-7519(92)90124-4. PMid:1428509.

R Development Core Team. R: a language and environment for statistical computing [online]. Vienna: R Foundation for Statistical Computing; 2017 [cited 2019 Sept 10]. Available from: http://www.R-project.org/

Ribeiro TS, Ghisi NC, Prioli AJ, Oliveira EC, Takemoto RM. Diversity of nematodes of red-tail-lambari Astyanax aff. paranae (Teleostei: Characidae) from polluted sites of a tropical river system. Neotrop Helminthol 2013; 7(2): 271-281.

Rivadeneyra NLS, Mertins O, Cuadros RC, Malta JCO, de Matos LV, Mathews PD. Histopathology associated with infection by Procamallanus (Spirocamallanus) inopinatus (Nematoda) in farmed Brycon cephalus (Characiformes) from Peru: a potential fish health problem. Aquacult Int 2020; 28(2): 449-461. http://dx.doi.org/10.1007/s10499-019-00474-3.

Salgado-Maldonado G, Mendoza-Franco EF, Caspeta-Mandujano JM, Ramírez-Martínez C. Aggregation and negative interactions in low-diversity and unsaturated monogenean (Platyhelminthes) communities in Astyanax aeneus (Teleostei) populations in a Neotropical river of México. Int J Parasitol Parasites Wildl 2019; 8: 203-215. http://dx.doi.org/10.1016/j.ijppaw.2019.02.005. PMid:30891400.

Salgado-Maldonado G, Novelo-Turcotte MT, Caspeta-Mandujano JM, Vazquez-Hurtado G, Quiroz-Martínez B, Mercado-Silva $\mathrm{N}$, et al. Host specificity and the structure of helminth parasite communities of fishes in a Neotropical river in Mexico. Parasite 2016; 23: 61. http://dx.doi.org/10.1051/parasite/2016073. PMid:28004635. 
Simková A, Morand S, Matejusová I, Jurajda P, Gelnar M. Local and regional influences on patterns of parasite species richness of central European fishes. Biodivers Conserv 2001; 10(4): 511-525. http://dx.doi.org/10.1023/A:1016658427730.

Takemoto RM, Pavanelli GC, Lizama MAP, Lacerda ACF, Yamada FH, Moreira LHA, et al. Diversity of parasites of fish from the upper Paraná River floodplain, Brazil. Braz J Bio/ 2009;69(2 Suppl.): 691-705. http://dx.doi.org/10.1590/S1519-69842009000300023. PMid:19738975.

Tavares-Dias M, Dias-Júnior MBF, Florentino AC, Silva LMA, Cunha AC. Distribution pattern of crustacean ectoparasites of freshwater fish from Brazil. Rev Bras Parasitol Vet 2015; 24(2): 136-147. http://dx.doi.org/10.1590/S1984-29612015036. PMid:26154954.

Thieltges DW, Hof C, Borregaard MK, Dehling DM, Brandle M, Brandl R, et al. Range size patterns in European freshwater trematodes. Ecography 2011; 34(6): 982-989. https://doi.org/10.1111/j.1600-0587.2010.06268.x.

Thorsen DH, Mille KJ, Van Tassell JL, Hajagos JG. Infestation of the parrotfish Sparisoma cretense (Scaridae) by the fish louse Anilocra physodes (Isopoda: Cymothoidae) in the Canary Islands. Cybium 2000; 24(1): 45-59.

Timi JT, Rossin MA, Alarcos AJ, Braicovich PE, Cantatore DMP, Lanfranchi AL. Fish trophic level and the similarity of non-specific larval parasite assemblages. Int J Parasito/ 2011; 41(3-4): 309-316. http://dx.doi.org/10.1016/j.ijpara.2010.10.002. PMid:21081133.

Travassos L, Artigas P, Pereira C. Fauna helmintológica dos peixes de água doce do Brasil. Arq Inst Biol (Sao Paulo) $1928 ; 1: 5-82$.

Val AL. Fishes of the Amazon: diversity and beyond. An Acad Bras Cienc 2019; 91(Suppl. 3): e20190260. http://dx.doi. org/10.1590/0001-3765201920190260. PMid:31166477.

Valladão GMR, Gallani SU, Jerônimo GT, Seixas AT. Challenges in the control of acanthocephalosis in aquaculture: special emphasis on Neoechinorhynchus buttnerae. Rev Aquacult 2019; 12(3): 1360-1372. http://dx.doi.org/10.1111/raq.12386.

Vicente J, Rodrigues HO, Gomes DC. Nematóides do Brasil. $1^{\text {a }}$ parte: nematóides de peixes. Atas Soc Biol 1985; $25:$ 1-79.

Zar JH. Biostatistical analysis. 5th ed. New Jersey: Prentice Hall; 2010. 
Patterns of Procamallanus (S.) inopinatus

\section{Supplementary Material}

Supplementary material accompanies this paper.

Table S1. Collection of data on Procamallanus (Spirocamallanus) inopinatus.

This material is available as part of the online article from https://www.scielo.br/rbpv e conferir se a página da rbpv na scielo abre corretamente 